\title{
OBSERVATIONS ON THE PREDACIOUS HABITS AND PREY OF COENOSIA HUMILIS, MG. (ANTHOMYIIDAE)
}

\author{
By Miss Alwen M. Evans, D.Sc.
}

(Lecturer in Entomology, Liverpool School of Tropical Medicine.)

[Read October 1st, 1930.]

Acknowledgments. I wish to take an early opportunity of expressing my very great indebtedness to Professor Poulton, whose kind interest in a random observation led me to collect these records and whose generous and untiring help has made it possible to present them in the form of this paper. The tabulated statement which forms the main part of the paper was kindly drawn up by Professor Poulton himself. It is a great pleasure also to acknowledge the invaluable assistance of the following authorities who have determined the material, a task which must have been rendered difficult in many cases owing to the mangled condition of the insects. Mr. J. E. Collin has determined the three captors and those of the prey to which the initials "J.E.C." are added in the tabulated statement. Mr. F. W. Edwards identified all the rest of the Dipterous prey, Mr. W. E. China the Hemipterous prey, Mr. J. V. Pearman the Psocopterous prey, and Mr. F. Laing the Aphid.

\section{Earlier Records of the Predacious Habit in the Anthomyiddae.}

The first definite record of the predacious habit among the ANTHOMYIIDAE is that given by Professor Poulton in Part I of his paper on Predaceous Insects and their Prey. The species was Coenosia (Caricea) tigrina, a specimen of which was taken with an Empid as prey in 1902. In discussing this record Professor Poulton states that he was informed that the Coenosinae were known to be predacious, but he emphasises the need for further specially directed observations on the nature of the prey in these predacious ANTHOMYIIDAE. Some later records refer to the genus Lispa, species of which have been seen by at least two observers preying on different stages of CULICIDAE. Lispa sinensis, Schiner, was seen in hundreds eating mosquito larvae at the surface of stagnant drains near Hong Kong by Dr. J. M. Atkinson (1909), and Dr. Lamborn (1920) has observed an undetermined species of the genus in large numbers attacking adults, larvae and pupae of mosquitoes in Nyasaland. The Lispa were seen to thrust their probosces into the thorax of larvae and withdraw them from the water; they also pounced on species of Culex just as these were emerging from the pupal case. In the Federated Malay States the same observer (1921) saw a species of Lispa " carrying on their useful work " in such numbers that he attributed the entire absence of Anopheles larvae from certain pools and ponds partly to their agency.

\section{Observations on Coenosia hUMilis.}

During the summer of 1926 I was fortunate enough to observe considerable numbers of Coenosia humitis in my garden. In June of that year a specimen of this species with what appeared to be prey was, at Professor Newstead's suggestion, sent to Professor Poulton, who replied saying that further observations on the prey of this Anthomyiid would be of interest. From the 28th

TRANS, ENT, SOC. LOND, LXXVIII. PART, II-(DEC. 1930). 


\begin{tabular}{|c|c|}
\hline $\begin{array}{l}\text { Prey of Coenosia (Caricea) } \\
\text { humilis, Mg. Prey with } \\
\text { asterisked Nos. taken by } \sigma^{\star} \\
\text { others by }+ \text {. }\end{array}$ & $\begin{array}{l}\text { Date and circumstances of capture-the Coenosia and } \\
\text { its prey together unless otherwise stated-in the } \\
\text { garden of } 33 \text { Greenhill Avenue, Calderstones } \\
\text { district, Liverpool, } 1926 \text {. }\end{array}$ \\
\hline 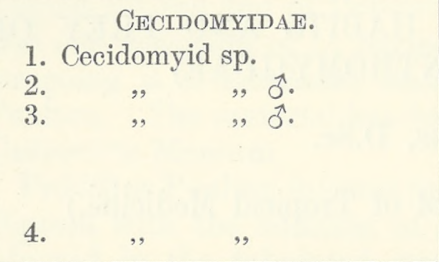 & $\begin{array}{l}\text { On leaf Michaelmas Daisy, } 8.10 \text { p.m., } 31 . \text { viii. } \\
", ", \quad 8.5 \text { p.m., } 2.1 x \text {. } \\
\text { " } ", \quad 6.35 \text { p.m., 15.ix. Very } \\
\text { violent shaking and jerking of collecting box } \\
\text { necessary to cause release of prey. Prey reduced } \\
\text { to very light condition. } \\
\text { On leaf of apple tree, c. } 6.30 \text { p.m., 23.ix. }\end{array}$ \\
\hline 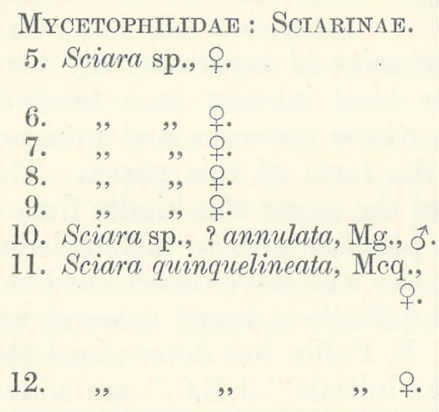 & $\begin{array}{l}\text { Placed in collecting box and caught by captor, } \\
6.33 \text { p.m., } 29 . \text { viii. } \\
\text { Taken on small table in bright sunshine, } 4.0 \text { p.m., 5.ix. } \\
\text { 17.ix. } \\
\text { Taken on plant, } 19 . i x . \\
5.0-6.0 \text { p.m., } 2 . x \text {. } \\
\text { On Michaelmas Daisy, } 8.12 \text { p.m., 31.viii. } \\
\text { On leaf of Marguerite or Michaelmas Daisy, } 9.30 \text { p.m., } \\
29 . v i \text {. } \\
\text { The Coenosia was apparently holding the small } \\
\text { fly and appeared to be applying its proboscis to it. } \\
\text { On leaf, } 8.0-8.15 \text { p.m., 3.ix. }\end{array}$ \\
\hline $\begin{array}{l}\text { MYCeTOPHILIDAE : MYCETO. } \\
\text { PHILINAE. } \\
\text { 13. Cordyla } \mathrm{sp} ., \sigma^{\star} \text {. }\end{array}$ & $5.0-6.0$ p.m., 2.x. \\
\hline 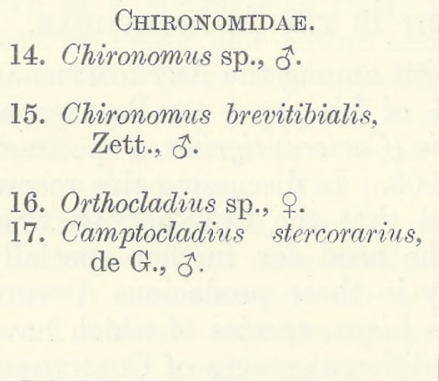 & 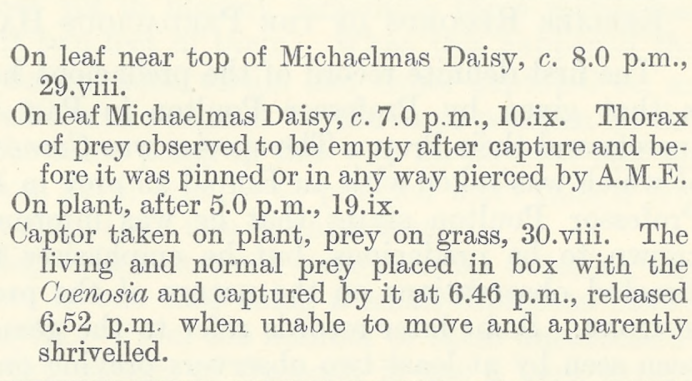 \\
\hline $\begin{array}{l}\text { CERAtopogonidaE. } \\
\text { 18. Culicoides obsoletus, Mg. } \\
\text { (= varius, Winn.), } q \text {. }\end{array}$ & $\begin{array}{l}\text { c. } 7.30 \text { p.m., } 29 . v i i i \text {. The prey was accidentally lost } \\
\text { after determination. }\end{array}$ \\
\hline 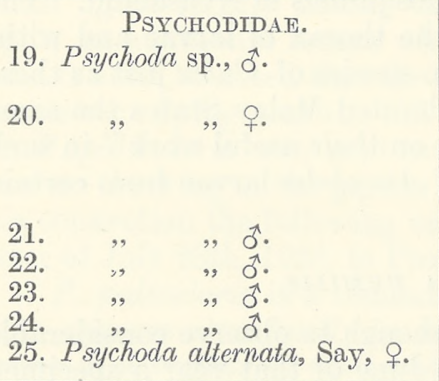 & $\begin{array}{l}\text { On roseleaf, } 8.20 \text { p.m., 28.viii. Prey (accidentally lost } \\
\text { after naming) not retained after capture by A.M.E. } \\
\text { On top of Michaelmas Daisy, c. } 8.0 \text { p.m., } 28 . v i i i . \\
\text { Caricea held prey between anterior legs. Pro- } \\
\text { boscis evidently applied or even inserted for } c .1 \\
\text { min. after capture. Appeared to be sucking. } \\
\text { On leaf c. } 4 \text { ft. from ground, } 8.0-8.15 \text { p.m., 3.ix. } \\
\text { On leaf, c. } 8.0 \text { p.m., 3.ix. } \\
\text { On leaf, c. } 7.0 \text { p.m., 9.ix. } \\
\text { On leaf, c. } 6.45 \text { p.m., 19.ix. } \\
\text { On high plant, } 3.0 \text { p.m., } 23 . i x \text {. }\end{array}$ \\
\hline $\begin{array}{l}\text { EPHYDRIDAE : HydRELIINAE. } \\
\text { 26. Philhygria vittipennis, Zett., } \\
\text { ठึ. (J.E.C.) }\end{array}$ & On rosebud in bright sunshine, 3.10 p.m., 5.ix. \\
\hline $\begin{array}{l}\text { Chloropidat. } \\
\text { 27. Oscinis frit, L., ․ (J.E.C.) } \\
\text { 28. " " ", भ. ( } \quad \text { " })\end{array}$ & $\begin{array}{l}\text { On leaf, c. } 4 \mathrm{ft} \text {. from ground, } 6.0 \text { p.m., 9.ix. The } \\
\text { Coenosia had to be shaken before releasing prey. } \\
\text { On leaf, c. } 3 \mathrm{ft} \text {. from ground, } 3.40 \text { p.m., } 11 . i x \text {. }\end{array}$ \\
\hline
\end{tabular}




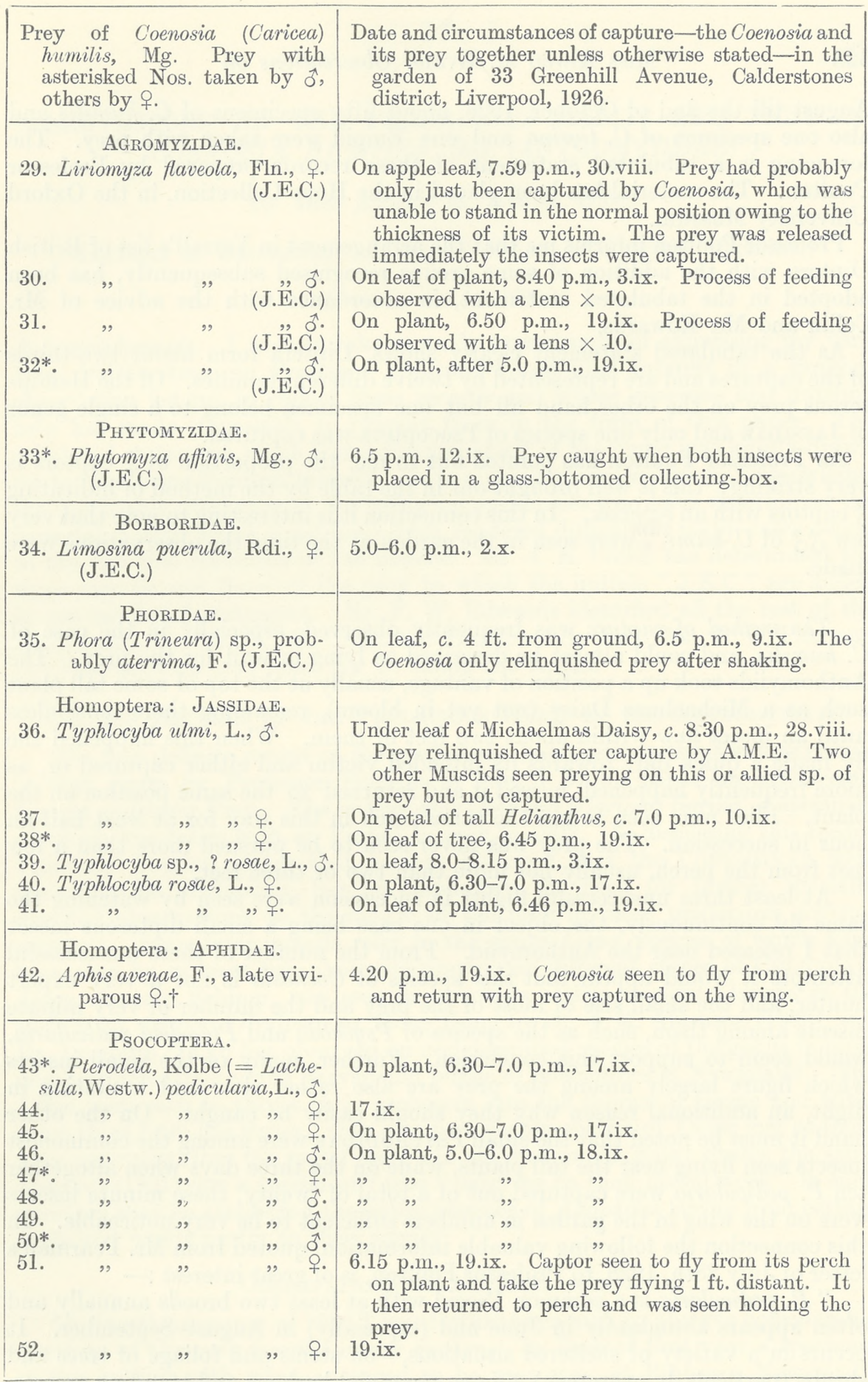

$\dagger \mathrm{Mr}$. F. Laing informs me that this Aphis is a very common species which migrates between the apple (and various other species of Pyrus) and wheat, oats and grasses generally.

Prey of Coenosia (Caricea) tigrina, F., ㅇ.

Psychoda alternata, Say, ‥ On top Michaelmas Daisy, 7.45 p.m., 28.viii. Prey relinquished after capture by A.M.E.

\section{Prey of Tachydromia minuta, Mg., 우 (EMPIDAE).}

Liriomyza Alaveola, Fln., §. (J.E.C.) On leaf of apple tree, 6.30 p.m., 15.ix. Prey clasped by first and second pairs of legs, head being attacked when taken. Violent shaking necessary to cause release of prey. 
August till the 2nd of October, 1926, about fifty specimens of $C$. humilis and also one specimen of $C$. tigrina and one Empid were taken with prey. The foregoing is a tabulated statement of these records prepared by Professor Poulton. The material has been placed in the Hope Collection, in the Oxford University Museum.

Professor Poulton informs me that the arrangement in Verrall's list of British Diptera with the addition of some groups recognised subsequently, has been adopted in the tabulated statement, in accordance with the advice of $\mathrm{Mr}$. Collin and Mr. Edwards.

As the tabulated statement clearly shows, Diptera form about two-thirds of the captures and are represented by twelve different families. Of the Hemipterous prey on the other hand all but one specimen belong to a single genus of JASSIDAE and only one species of Psocoptera was captured.

As Professor Poulton has pointed out to me, the proportion of $q$ captors is very striking; this is well brought out in the table by the method of indicating o captors with an asterisk. In this connection it is interesting to note that very few $\vec{\delta} \hat{\delta}$ of $C$. humitis were seen in the garden at the time the observations were made.

The method of capture was frequently observed, especially in the case of C. humilis, and could almost be described as lying in wait for the prey. The Anthomyiids took up a position of vantage, usually at the top of some tall plant such as a Michaelmas Daisy (not yet in bloom), remaining there motionless until an insect flew within about two feet of them. When this happened the fly made a quick dart towards its intended victim and either captured or, as more frequently happened, missed it and returned to the same position on the plant. Flies were seen to use the same perch in this way for at least half an hour in succession. The prey was never seen to be pursued more than a few feet from the perch, usually not more than two or three feet.

At least three unsuccessful flights in succession were seen by watching the same fly continuously, the object in one case being a small dipterous insect that I released near the Anthomyiid. From the number of these unsuccessful attempts it would appear that this species of Coenosia is not a very expert hunter, and the small size of most of the prey and the number of very minute insects among them, such as the species of Psychoda and Pterodela pedicularia, would seem to support this conclusion. Further, many of the small insects which figure largely among the prey are also rather slow and hesitating in flight, an additional reason why they should easily be caught. On the other hand it must be noted that the small PSYCHODIDAE were among the commonest insects seen flying near the tall plants, while on the three days when altogether ten $P$. pedicularia were captured out of a total of twenty, these minute insects were on the wing in the garden in numbers sufficient to be very noticeable. In this connection the following valuable information, quoted from Mr. Pearman's letter of July 28th, 1928, to Professor Poulton, is of great interest :-

" $P$. pedicularia is a common Psocid with at least two broods annually and often appears abundantly in June and (especially) in August-September. It occurs in a variety of sheltered situations,--on stems and foliage of trees and shrubs (particularly evergreen), among perennial herbage and standing grasses, and on fallen dead leaves, in chaff, etc. It readily takes wing, and swarming flights (migratory) are frequent in late summer (cf. Hart, 1880, Ent. Mon. Mag., 71: 141). At such times it will enter houses and stores where, if the necessary food substances are available, a subsequent brood will develop, but the mature 
individuals of this generation always endeavour to get out to the open and are then found swarming on windows (cf. MacLachlan, 1867, Ent.Mon. Mag., 3 : 271). The food consists of pleurococcus, micro-fungi, dead insects, and insects' eggs."

It seems certain that such a swarming flight was taking place in the garden on the days when the Psocid was caught in such numbers by the Coenosia.

From the method of capture and from the fact that I never saw an attempt at the seizure of a motionless insect, or in nature of one that was not in flight, it would appear likely that the prey is detected by its movement.

On three occasions the actual capture of the prey in nature was seen, but in one case the captor was not secured; it was apparently a o $C$. humilis. This capture took place a few feet above a tall plant, and a short struggle was seen to occur before the prey, a large Chironomid, was brought to the perch to be consumed. In the other cases (Nos. 42 and 51 in the table) the prey was smaller and the capture was made almost instantaneously. Captures were also made by $C$. humilis placed in small glass-bottomed boxes (about $1 \frac{1}{2} \times 11^{1}{ }^{\prime \prime}$ ), together with small Diptera. The captors were females on two occasions and a male on the third and, in each case, the small fly was caught in less than ten minutes. In one instance it was clearly seen that the fore-legs of the fly were used in capturing the prey.

The prey was not killed immediately, and not, of course, paralysed. This was clearly shown once when a $C$. humilis with newly caught prey released its victim at the moment they were boxed, and the prey, a species of Chironomus (No. 14), was able to walk when released by the captor.

Method of feeding. The process of ingesting the tissues of the prey could be observed in detail, through a lens magnifying 10 diameters, when the Anthomyiids happened to consume their meal near the glass side of a collectingbox. In the case of a fairly substantial fly such as Liriomyza flaveola the process took as long as twelve minutes. The prey was held between the captor's fore-legs and its head was forced downwards. The Anthomyiid then inserted its proboscis into the thorax through the neck but outside the oesophagus. By rapid up-and-down movement of its proboscis the captor extracted the tissues from the prey, and, in time, the thorax became so empty that the dark labium could be seen through its walls, and it was noticed that the labella scraped along the inside of the thoracic wall scooping out the remains of the tissues. When the thorax was quite emptied the head was attacked through the occipital foramen, and lastly the abdomen, an incision being made near the base and the proboscis inserted several times until the contents were absorbed. This order of procedure was observed with two specimens of L. flaveola (Nos. 30 and 31 in the tabulated statement). When the prey was smaller and more delicate (No. 5), the process was much quicker, only occupying about two minutes and the contents of the thorax and abdomen appeared to be absorbed through the thoracic opening.

\section{REFERENCES.}

Atkinson, J. M. (1909). "A possible natural enemy of the mosquito." J. Trop. Med. Hyg., 12 : 253.

Lamborn, W. A. (1920). "The habits of a Dipteron predaceous on mosquitoes in Nyasaland." Bull. Ent. Res., 11: 279.

(1921). Fed. Malay States Malaria Bureau Report for year 1920, Supp. F.M.S. Gov. Gaz., pp. 8-13.

Poulton, E. B. (1906). "Predaceous Insects and their Prey." Trans. Ent. Soc. Lond., 1906 : 323-409.
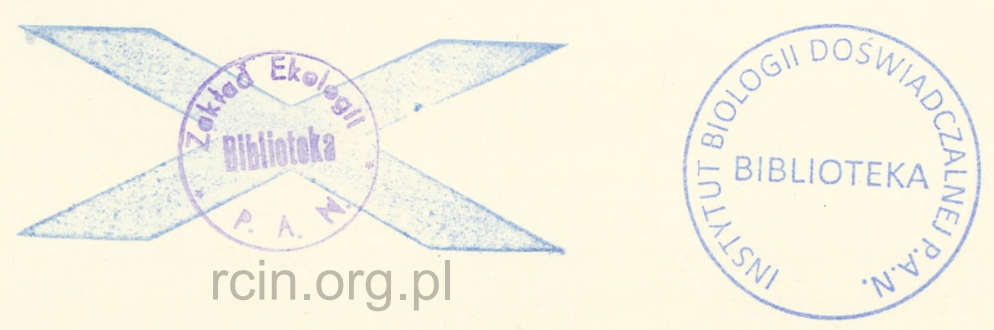
Printed in Great Britain by RICHARD CLAY \& SONS, LIMITED, BUNGAY, SUFFOLK. 